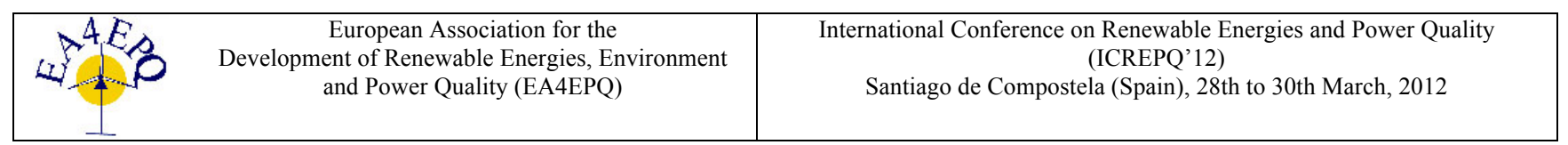

\title{
Energy and Greenhouse Gas Analysis for Biogas Power Plants
}

\author{
Wolfgang Bauer ${ }^{1}$, Stefan Bauer ${ }^{2}$ and Thomas Bauer ${ }^{2}$ \\ ${ }^{1}$ Department of Physics and Astronomy, Michigan State University \\ East Lansing, MI 48824-2320, USA \\ e-mail: bauer@pa.msu.edu \\ ${ }^{2}$ CPM Biogas GmBH \& Co KG, D-61130 Nidderau, Germany
}

\begin{abstract}
In order to assess the efficiency of an alternative power source and to provide a meaningful comparison with fossil fuel based power sources, a complete accounting of all energy input and output streams, as well as all greenhouse gases, is necessary. We present this analysis for a $1.45 \mathrm{MW}(0.71 \mathrm{MW}$ electrical) biogas power plant operating with $70 \%$ corn silage and $30 \%$ cow dung feedstock. We find net energy ration of 8.0, a net efficiency of $1.2 \%$ of converting solar energy into electricity and usable heat, and that only $16 \mathrm{~g} \mathrm{CO}_{2}$ per kWh are generated in the process. If all greenhouse gases are considered, our process even actively reduces the total greenhouse gas load on the atmosphere. In terms of producing transportation biofuels our plant provides 3.8 times more yield per hectare than bioethanol plants.
\end{abstract}

\section{Key words}

Biofuels, biogas, bioethanol, greenhouse gas analysis, net energy analysis.

\section{Introduction}

Due to the work of Keeling [1] and many others it has become clear that the carbon-dioxide concentration in our atmosphere is rising steadily. Approximately 15 billion tons of this gas are added annually, predominantly from burning of fossil fuels. Caused by this increase in anthropogenic greenhouse gases is a rise in the average global temperature [2]. We cannot predict with certainty what the effects of the rise of atmospheric greenhouse gases and associated global warming will be, but it seems prudent to avoid finding out. To this end many countries have begun large investments in alternative power sources, such as wind turbines, geothermal power plants, bioethanol production facilities, and solar-thermic or photovoltaic installations. Generating the approximately $15 \mathrm{TW}$ of current global power consumption requires use of all available technologies [3].

In order to have a real positive impact, however, we have to make sure that the alternative means of power production deployed to mitigate greenhouse gas emissions have a positive energy output and that they provide an effective net reduction in greenhouse gas emissions over their lifetime. This analysis must take into account the initial construction, plant and equipment maintenance, procurement of fuels, disposition of waste, and energy use during operation.

Among the biomass-based technologies, ethanol produced from corn has received the largest influx of investments. However, it is far from clear how much this mode of generating transportation fuels reduces net greenhouse gas emissions, if at all [4]-[6], and the same can be said for other energy plant feed stocks for bioethanol or biodiesel production $[6,7]$.

\section{Net Energy Life Cycle Analysis}

Here we report on the energy and greenhouse gas economy of another method to turn renewable biomass into electricity, heat, and/or transportation fuel: a biogas power plant.

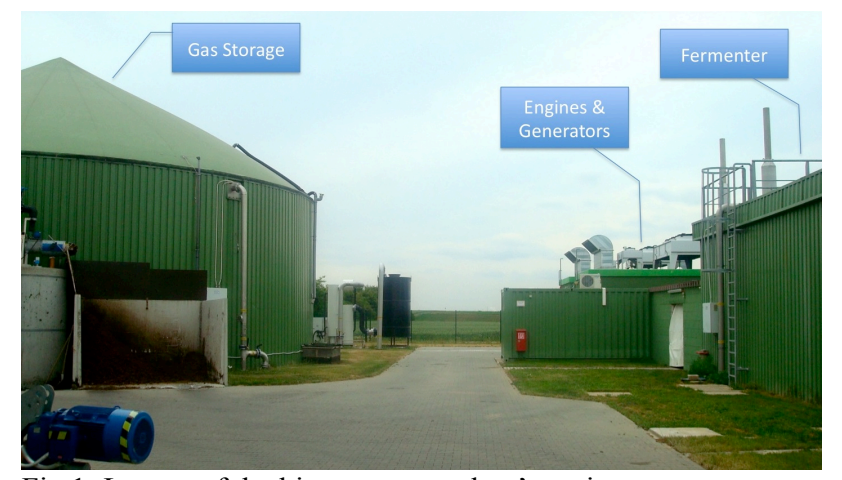

Fig.1: Layout of the biogas power plant's main components.

Biogas is mixture of carbon dioxide and methane (typically $60 \%$ by volume), which can be burned in highefficiency engines/generators to produce electricity. The basic principle to produce the biogas is the same that is employed in a cow's stomach: anaerobic fermentation. Suitable feed stocks for this type of power plant can be a wide variety of organic matter such as energy plants (corn, switchgrass, sugarcane...), restaurant food waste, lawn clippings, leaves, organic waste from water treatment plants, and even animal excrements. For the 
specific example presented here we used a 70/30 mixture of shredded corn (the entire plant, not just the cob) and cow dung. Fig. 1 shows a picture of the main components of this power plant.

We have run this power plant in the central part of Germany, just outside of Frankfurt, for five years without interruption and optimized its operation, keeping track of all energy inputs and outputs. The corn is grown on 150 hectares of land, with an average yield of 60 metric tons of corn (33-35\% dry substance) per hectare [8]. It is very important to note that we do not use any artificial irrigation and rely only on rain to provide water. Even more important for the energy and greenhouse gas accounting is that we do not use artificial fertilizer, but only spread the fermentation residue on the fields, which provides enough nutrients $(\mathrm{N}, \mathrm{P}, \mathrm{K}, \mathrm{Ca})$ to prevent soil deterioration and sustain plant growth.

In central Germany the growing season for corn extends from April to October, at which point the corn is shredded and stored in large silos. Approximately 25 metric tons of corn silage per day is mixed with 11 tons of cow dung and inserted into an anaerobic digester, where the biogas is produced. We find that an average of $100 \mathrm{~m}^{3} /$ ton of biogas are produced from the cow dung, and $240 \mathrm{~m}^{3} /$ ton of biogas are produced form the corn silage. Our biogas production is enhanced by approximately $10-20 \%$ with the aid of an enzyme/sugar mixture, of which we add $15 \mathrm{~kg}$ to the feed stock mixture every day. Each day approximately 30 tons of solid/liquid mixture fermentation residue is produced in this process, which is a high-quality organic fertilizer.

Our plant produces approximately $7100 \mathrm{~m}^{3}$ of biogas per day, which means that we generate approximately $4200 \mathrm{~m}^{3}$ of methane per day. This methane, approximately 1100 metric tons/year, could be liquefied and be used as a transportation fuel, or it could be pipelined to the end user. However, in our present mode of operation we burn the biogas in high-efficiency gas engines $(40 \%$ electric and $42 \%$ thermal coefficient of efficiency) to generate electricity and co-generate heat. Since the heat of combustion (lower heating value) for methane is 50 $\mathrm{MJ} / \mathrm{kg}$, this means that our plant generates approximately $17 \mathrm{MWh}$ of electricity and approximately $18 \mathrm{MWh}$ of heat per day, which means that our plant produces $6200 \mathrm{MWh}$ of electricity per year and $6500 \mathrm{MWh}$ of heat.

What is the total annual energy input required to generate these 12.7 GWh of energy? One big source of energy input is diesel fuel for the tractors and harvesters. We find that 71 liters of fuel per hectare are needed to prepare the soil, seed the corn, spray herbicides, and harvest the corn. Almost $50 \%$ of this total is used by the shredder/harvester operation alone. We account separately for the transportation of the shredded corn from the fields to the power plant and the fertilizer and herbicides from the plant to the fields. For the tractors and trailers used, a typical average is a load of 16 tons. This means that on average 9.4 round trips between the fields and the power plant are required per hectare each year. If the fields were arranged in a circle around the power plant, the mean distance between the fields and the power plant would be $0.87 \mathrm{~km}$, but we find that a realistic value is $2 \mathrm{~km}$. Using a typical number of 0.55 liter of diesel per $\mathrm{km}$ for the tractors, this translates into 20.6 liters/hectare of diesel consumed annually for transportation.

It has to be noted that the amount of diesel fuel spent on transportation is proportional to the square root of the total acreage of the fields and thus proportional to the power output of the farm. This means that for a power plant of approximately 10 times bigger size the transportation fuel would dominate the energy input calculations.

Another 3,000 liters per year are used for the operation of the feeder tractor. Thus the total diesel fuel consumed in growing, harvesting, and transporting the corn feed stock and in the plant operation is close to 17,000 liters. With a heat of combustion for diesel fuel of $10.4 \mathrm{kWh} /$ liter this means that this part of the operation consumes almost $180 \mathrm{MWh}$ annually.

The plant itself uses a variety of electric motors for pumps, actuators, compressors, valves, and controls. Collectively these consume $8 \%$ of the total produced electricity, almost $500 \mathrm{MWh}$ per year. In addition, we use approximately $2 \%$ of the produced thermal energy to heat the fermenter to the optimal operating temperature. This amounts to $130 \mathrm{MWh} /$ year.

The total labor involved is a half-time person for day-today plant operation and routine maintenance, 6 people working full-time during the harvest for one week, and 11 hours/hectare for a total of 0.79 man-years spent on working the cornfields. Thus it takes approximately 1.4 people to provide the entire labor for this operation. Since a person eats approximately 2500 food calories per day, he or she consumes approximately $1 \mathrm{MWh}$ in food each year. Therefore if one only counts the calories from food as energy input, the total annual energy costs in labor are a vanishingly small $1.4 \mathrm{MWh}$.

To estimate the total wear and tear on our farm equipment we follow the numbers produced by Pimentel and Patzek [6], which amounts to $1.18 \mathrm{MWh} /$ hectare, for a total of $180 \mathrm{MWh}$ of energy cost per year.

Corn seeds amount to an energy input of $0.60 \mathrm{MWh} /$ hectare, for a total of $92 \mathrm{MWh}$. We use approximately 3 liters of herbicides/pesticides per hectare. The price per liter for these chemicals is approximately 20 times that of diesel fuel; and so we budget, as an upper limit, each liter of herbicide the same as 20 liters of diesel fuel in our energy calculation. Therefore an upper limit for our annual energy consumption from herbicides/pesticides is $95 \mathrm{MWh}$. Finally, we add $15 \mathrm{~kg}$ of enzymes additives to our plant feedstock to enhance methane production. The price of $1 \mathrm{~kg}$ of this mixture is 3 times that of 1 liter of diesel fuel, which means a contribution of $171 \mathrm{MWh}$ debit to our energy calculations.

If we add up all of the external energy input listed here, we find a total of $715 \mathrm{MWh}$ used in the entire operation per year. The annual net energy production, after 
subtraction of the heat and electricity produced for the operation of the plant, is $12,100 \mathrm{MWh}$. The net energy output-to-input ratio is therefore 16.9 for our plant. If one only counts the produced electricity, then the output-toinput ratio is still 8.0. This compares very favourably to the input-to-output ratios for bioethanol, which range from below 1.0 [6] up to 2.2 [9].

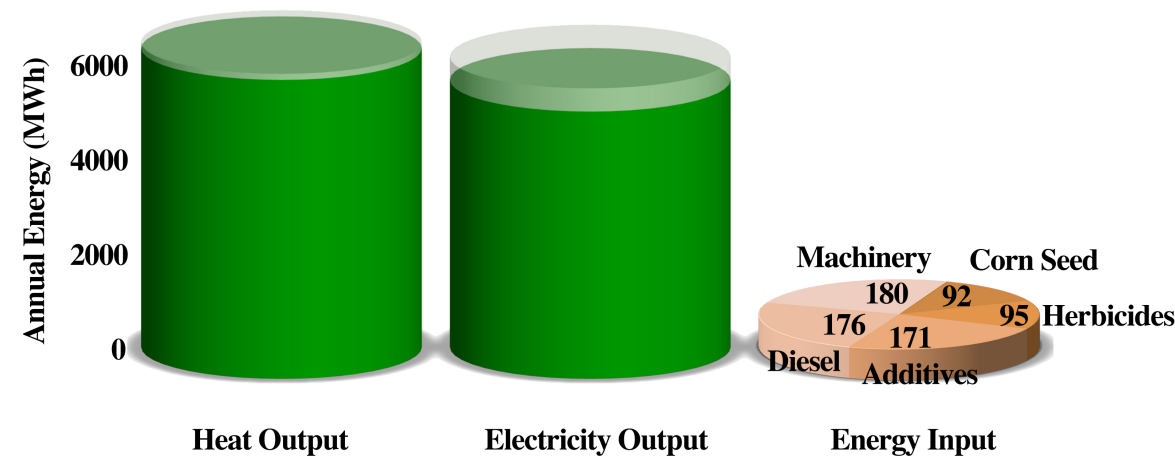

composition of the dung. In our operation we capture this methane and effectively turn it into $\mathrm{CO}_{2}$. This prevents between 50 and 120 tons of methane from entering the atmosphere each year. The global warming potential of methane is 25 times that of carbon dioxide ( 100 year time horizon). If we budget a savings of 25 tons of $\mathrm{CO}_{2}$ for each ton of $\mathrm{CH}_{4}$ sequestered in this way, then we arrive at a net $\mathrm{CO}_{2}$ output of between $-100 \mathrm{~g}$ and $-250 \mathrm{~g}$ per $\mathrm{kWh}$ of produced energy. If we consider only a 20year horizon, then the global warming potential of $\mathrm{CH}_{4}$ is approximately 70 times that of $\mathrm{CO}_{2}$, and our numbers are even better by a factor of $\sim 3$. No matter which assumptions and scenarios one uses, the bottom line is that the entire plant operation not only does not contribute to the greenhouse gas problem, but it provides a significant actual net mitigation!

Fig. 2: Total annual energy inputs (right column) and net energy outputs (left: heat, center: electricity) of our biogas power plant.

In Fig. 2 we provide a visual summary of all energy inputs (earth tones) and net energy outputs (solid green color). The semi-transparent tops of the green energy output columns represent the fractions of the produced electricity and heat, which are used for the plant operation.

\section{Solar Power Conversion Efficiency}

The total annual solar energy received by the central part of Germany [10] is $1.05 \mathrm{MWh} / \mathrm{m}^{2}$. The length of the corngrowing season is almost 5 months, during which the fields receive approximately $60 \%$ of the annual solar energy. This amounts to $800 \mathrm{GWh}$ of solar energy for our entire land area used for growing the corn. Therefore the integrated net solar efficiency of our biogas power plant is $1.2 \%$, and the net electrical efficiency is $0.6 \%$.

\section{Greenhouse Gas Accounting}

Diesel fuel combustion produces $2.68 \mathrm{~kg}$ of $\mathrm{CO}_{2}$ per liter of diesel [11]. The total $\mathrm{CO}_{2}$ production of our operation from diesel fuel consumption is therefore 45.4 tons. The fermentation enzymes (68.5 tons), herbicides/pesticides (23.7 tons), seeds, farm equipment wear and tear (46.4 tons) also add significant amount of $\mathrm{CO}_{2}$, for a total of 184 tons of $\mathrm{CO}_{2}$ produced by our entire plant operation per year. The net $\mathrm{CO}_{2}$ produced from the burning of the methane from the fermentation of the corn silage is zero, and so our total $\mathrm{CO}_{2}$ output is $16 \mathrm{~g}$ per $\mathrm{kWh}$ of produced energy. This number compares very favourably to $\sim 1 \mathrm{~kg}$ of $\mathrm{CO}_{2}$ produced per $\mathrm{kWh}$ from the burning of coal in power plants, for example. It makes our power plant close to carbon-neutral.

However, if we look at the entire greenhouse gas emission, then the picture that emerges is even more positive. We use 11 tons of cow dung per day, each of which releases $100 \mathrm{~m}^{3}$ of methane [12]. Used as a conventional agricultural fertilizer, a large fraction of this methane would escape into the atmosphere, between $30 \%$ and $70 \%$, depending on spreading techniques, storage times, and

\section{Transportation Fuel Production}

If transportation fuel production is the ultimate goal, then our present plant is able to produce 2.6 million liters of liquid methane per year. Pimentel $[6,13]$ calculates that one can generate 1 liter of ethanol from $2.69 \mathrm{~kg}$ of corn grain. Using our corn silage production of 60 tons/hectare and our corn grain production of 12 tons/hectare, the same area used by us would yield 0.68 million liters of ethanol. This number of $\sim 4,500 \mathrm{~L} / \mathrm{ha}$ is consistent with the range of yields reported in [9], between 4,000 and 5,600 L/ha.

Since the heat of combustion per liter for methane and for ethanol are nearly identical, our process produces approximately 3.8 times more usable transportation fuel per hectare than bioethanol production. This is even higher than what was determined in [14,15]. A highly fuel-efficient compact car uses 6 liter of gasoline per 100 $\mathrm{km}$ [16], which would correspond to 9 liter of methane or ethanol with suitably retrofitted engines. The annual methane output of our plant would allow to one drive this car for 29 million $\mathrm{km}$. (Converting a car with a gasoline engine to one that can drive on methane is fairly inexpensive, around $\$ 3,000$.) If we were to feed the annual electricity produced by our plant in a compact electric car (55 km driving distance per $10 \mathrm{kWh}$ charge), one could drive it for 35 million $\mathrm{km}$.

\section{Food vs. Fuel}

Whenever one utilizes biological feedstock from energy plants for biofuel purposes, the question of "food vs. fuel" has to be addressed. Will people go hungry because of increased biofuel production? The answer is no, as long as there is farmland, which would remain fallow otherwise. In the USA, for example, more than 13 million hectares of farmland are kept out of farming via the Conservation Reserve Program. In the EU, too, farmers are paid to avoid growing crops on some of their land. A large fraction of this land can be used to grow 
energy plants for biofuels without any negative impact on food supplies or food prices.

Obviously, there is an upper limit of the total land area, which can be devoted to biofuels without causing food shortages. But whatever this upper limit is, our process can obtain 3.8 times more transportation fuel off that area than what can be achieved via bioethanol production.

\section{Conclusion}

In summary, our five-year experiment clearly shows that biogas production through biological fermentation in an anaerobic digester is a viable way to convert solar energy into electricity and/or transportation fuel, that this process is much more efficient than the production of bioethanol, and that it is close to carbon-neutral and even actively reduces the total greenhouse gas load on the atmosphere.

Electricity and methane are much easier to transport than ethanol and can easily utilize existing transportation networks (power lines and natural gas pipelines). Since our entire plant infrastructure can be recreated for approximately \$3-\$5 million, and since this initial investment can be recouped after approximately 4 years, any corn farm of $>150$ hectares in size can be converted into an independently owned power plant. Thus our approach is easily scalable to wherever corn is presently grown for the purpose of generating biofuels. Our results suggest that it is time to re-examine how one utilizes biomass, and in particular corn, for energy and/or liquid biofuels production. In the USA alone, corn-ethanol production is projected to reach 50 billion liters within the next five year. Our results suggest that one could harvest 190 billion liters of methane from the same land area.

\section{References}

[1] C.D. Keeling, Tellus 12(2), 200 (1960).

[2] R. K. Pachauri, Intergovernmental Panel on Climate Change (IPCC), Nobel Lecture, 10 December 2007 (http://nobelprize.org/nobel_prizes/peace/laureates/2007/ ipcc-lecture_en.html)

[3] R.H. Socolow and S.W. Pacala, Scientific American, September 2006, p. 50.

[4] T. Searchinger, Science 319, 1238 (2008).

[5] D. Charles, Science 324, 587 (2009).

[6] D. Pimentel and T.W. Patzek, Natural Resources Research 14(1), 65 (2005)

[7] M.R. Schmer, K.P. Vogel, R.B. Mitchell, and R.K. Perrin, PNAS 105(2), 464 (2008).

[8] The USDA reports an average of 19.3 tons/acre $(=47.7$ tons/hectare) yields for 2010. http://www.nass.usda.gov/ Statistics by Subject/index.php?sector=CROPS. The same data source lists the corn grain yield as 12.0 tons/hectare, using $70 \mathrm{~kg} / \mathrm{bushel}$ for corn.

[9] Adam J. Liska, Haishun S. Yang, Virgil R. Bremer, Terry J. Klopfenstein, Daniel T. Walters, Galen E. Erickson, and Kenneth G. Cassman, Journal of Industrial Ecology 13, 58 (2009).

[10] M. Súri, T.A. Huld, E.D. Dunlop, H.A. Ossenbrink, Solar Energy 81, 1295-1305, (2007) http://re.jrc.ec.europa.eu/pvgis/.

[11] http://www.eia.gov/oiaf/1605/coefficients.html.

[12] Similar, but slightly lower, numbers can be found at http://www.fnr.de.

[13] D. Pimentel, Jour. Agri. Environ. Ethics 4, 1 (1991).

[14] J. Ohlrogge, D. Allen, B. Berguson, D. DellaPenna, Y. Shachar-Hill, S. Stymne, Science 324, 1020 (2009).

[15] J. E. Campbell, D. B. Lobell, C. B. Field, Science 324, 1055 (2009).

[16] 2011 fuel efficiency data, http://www.fueleconomy.gov/ feg/pdfs/guides/FEG2011.pdf. For our comparison we used the data for the gas and electric engines of the Chevy Volt. 